Shutenko Oleg Volodymyrovych, Candidate of Technical Sciences, Docent, Associate Professor of the Electric Power Transmission Department

Kulyk Oleksii Serhiiovych, PhD Student of the of the Electric Power Transmission Department

National Technical University "Kharkiv Polytechnic Institute", Kharkiv, Ukraine, Kyrpychova str., 2, 61002

\title{
RECOGNITION OF DISCHARGES THAT ARE ACCOMPANIED BY LOW- TEMPERATURE OVERHEATING BASED ON THE ANALYSIS OF GASES DISSOLVED IN THE OIL OF HIGH-VOLTAGE TRANSFORMERS
}

\begin{abstract}
Based on the analysis of test results for 135 high-voltage transformers, ranges of gas percentage, gas ratio values were obtained and nomograms for 10 types of combined defects were made, representing discharges with different intensity which are accompanied by overheating with temperature of $150-300^{\circ} \mathrm{C}$. It has been established that in transformers with discharges accompanied by low-temperature overheating the values of $\mathrm{CH} 4 / \mathrm{H} 2, \mathrm{C} 2 \mathrm{H} 2 / \mathrm{CH} 4, \mathrm{C} 2 \mathrm{H} 2 / \mathrm{C} 2 \mathrm{H} 6$ and $\mathrm{C} 2 \mathrm{H} 2 / \mathrm{C} 2 \mathrm{H} 4$ ratios determine the discharge energy, in accordance with the norms regulated by the most known standards, the C2H4/C2H6 ratio varies slightly depending on the hot spot temperature and the $\mathrm{C} 2 \mathrm{H} 6 / \mathrm{CH} 4>1$ ratio value. Dynamics of defects nomograms changing in the process of their development is analyzed. It is stated by the analysis results that in majority of cases the primary defect is discharges with different intensity, which are accompanied by low-temperature overheating. Overheating occurs in the process of discharge development. The analysis of recognition reliability of discharges with different intensity which are accompanied by $150-300^{\circ} \mathrm{C}$ overheating was made, using norms and criteria regulated by the most known standards and methods. The results of the analysis show that the most reliable recognition of the defects analyzed is provided to a large extent by the graphical methods, namely the ETRA square and the Duval triangle. The results obtained will significantly increase the recognition reliability of combined defects based on the results of the dissolved gas analysis in the oil.
\end{abstract}

Keywords: power transformers, dissolved gas analysis, combined defects, discharges and low-temperature overheating, diagnostic criteria, dynamics of the defect development, diagnostic reliability.

Шутенко Олег Володимирович, канд. техн. наук, доцент, доцент кафедри передачі електричної енергії Кулик Олексій Сергійович, аспірант кафедри передачі електричної енергії

Національний технічний університет «Харківський політехнічний інститут», м. Харків, Україна, вул. Кирпичова, 2, 61002

\section{РОЗПІЗНАВАННЯ РОЗРЯДІВ, ЯКІ СУПРОВОДЖУЮТЬСЯ НИЗЬКОТЕМПЕРАТУРНИМИ ПЕРЕГРІВАМИ ЗА РЕЗУЛЬТАТАМИ АНАЛІЗУ РОЗЧИНЕНИХ У МАСЛІ ГАЗІВ ВИСОКОВОЛЬТНИХ ТРАНСФОРМАТОРІВ}

\begin{abstract}
Анотація. На підставі аналізу результатів випробувань по 135 високовольтним трансформаторам отримані діапазони значень відсоткового вмісту газів, значення відношень газів і побудовані номограми для 10 типів комбінованих дефектів, щуо представляють собою розряди з різним ступенем інтенсивності, які супроводжуються перегрівами з температурою 150-300 ${ }^{\circ}$. Встановлено, щчо в трансформаторах 3 розрядами, які супроводжуються низькотемпературними перегрівами, значення відношень: СН4/Н2, $\mathrm{C} 2 \mathrm{H} 2 / \mathrm{CH} 4, \quad \mathrm{C} 2 \mathrm{H} 2 / \mathrm{C} 2 \mathrm{H} 6$ i C2H2/C2H4 визначають енергію розрядів, відповідно до норм, щзо регламентуються у більшості відомих стандартів, значення відношення С2Н4/С2Н6 незначно варіюється залежно від температури «гарячої точки», а значення відношення C2H6/CH4>1. Проаналізовано динаміку зміни номограм дефектів у процесі їх розвитку. За результатами аналізу встановлено, шуо при розвитку розрядів з різним ступенем інтенсивності, які супроводжуються перегрівами в діапазоні низьких температур, у більшості випадків первинним дефектом є саме розряди. Перегріви виникають вже в процесі розвитку розрядів. Виконано аналіз достовірності розпізнавання розрядів з різним ступенем інтенсивності, які супроводжуються перегрівами з температурою $150-300^{\circ} \mathrm{C}$, з використанням норм $i$ критеріїв, регламентованих найбільш відомими стандартами і методиками. За результатами аналізу встановлено, щзо найбільшу достовірність розпізнавання, стосовно аналізованих дефектів забезпечують більшою мірою графічні методи, а саме квадрат ЕТРА і трикутник Дюваля. Отримані результати дозволять істотно підвищити достовірність розпізнавання комбінованих дефектів за результатами аналізу розчинених у маслі газів.
\end{abstract}

Ключові слова: силові трансформатори, аналіз розчинених у маслі газів, комбіновані дефекти, розряди $i$ низькотемпературний перегрів, діагностичні критерії, динаміка розвитку дефекту, достовірність діагностики. 
Шутенко Олег Владимирович, канд. техн. наук, доцент, доцент кафедры передачи электрической энергии Кулик Алексей Сергеевич, аспирант кафедры передачи электрической энергии

Национальный технический университет «Харьковский политехнический институт», г. Харьков, Украина, ул. Кирпичева, 2, 61002

\section{РАСПОЗНАВАНИЕ РАЗРЯДОВ, КОТОРЫЕ СОПРОВОЖДАЮТСЯ НИЗКОТЕМПЕРАТУРНЫМИ ПЕРЕГРЕВАМИ ПО РЕЗУЛЬТАТАМ АНАЛИЗА ГАЗОВ, РАСТВОРЕННЫХ В МАСЛЕ ВЫСОКОВОЛЬТНЫХ ТРАНСФОРМАТОРОВ}

Аннотация. На основании анализа результатов испытаний по 135 высоковольтным трансформаторам получень диапазонь значений прочентного содержания газов, значений отночений газов и построень номограмм для 10 типов комбинированных дефектов, представляюших собой разряды с разной степенью интенсивности которые сопровождаются нагревом с температурой 150-300 $\mathrm{C}$. Установлено, что в трансформаторах с разрядами, которые сопровождаются низкотемпературными перегревами значения отнотений: CH4/H2, C2H2/CH4, C2H2/C2H6 и C2H2/C2H4 определяют энергию разрядов, в соответствии с нормами регламентируемыми в большинстве известных стандартов, значение отношения С2H4/C2H6 незначительно варьируется в зависимости от температуры горячей точки, а значение отночения C2H6/CH4>1. Проанализирована динамика изменения номограмм дефектов в прочессе их развития. По результатам анализа установлено, что при развитии разрядов с разной степенью интенсивности, которые сопровождаются перегревами в диапазоне низких температур, в большинстве случаев первичным дефектом являются именно разряды. Перегревы возникают уже в проиессе развития разрядов. Выполнен анализ достоверности распознавания разрядов с разной степенью интенсивности, которые сопровождаются нагревом с температурой $150-300^{\circ} \mathrm{C}, \mathrm{c}$ использованием норм и критериев, регламентируемых наиболее известными стандартами и методиками. По результатам анализа установлено, что наибольшую достоверность распознавания, применительно к анализируемым дефектам обеспечивают в большей степени графические методы, а именно квадрат ЕТРА и треугольник Дюваля. Полученные результаты позволят существенно повысить достоверность распознавания комбинированных дефектов по результатам анализа растворенных в масле газов.

Ключевье слова: силовые трансформаторы, анализ растворенных в масле газов, комбинированные дефекты, разряды и низкотемпературный перегрев, диагностические критерии, динамика развития дефекта, достоверность диагностики.

Introduction. One of the ways to reduce the damageability of high-voltage power transformers, especially those operating beyond their standard service life, is the development of new and improvement of existing methods of non-destructive diagnostics. One of these methods, which have found the widest application, both in Ukraine and abroad, is the dissolved gas analysis (DGA). This method makes it possible not only to detect defects, which develop in oilfilled equipment at an early stage, but also to recognize their type. The latter circumstance is fundamentally important when deciding on the possibility of further operation of equipment, which imposes rather high requirements for the reliability of defect type recognition. Currently, the DGA method enables to recognize both defects of electrical type (partial, spark, creeping and arc discharges) and thermal defects (overheating with different "hot spot" temperature). However, during operation combined defects may occur, such as discharges accompanied by overheating or overheating transforming into discharges. Diagnostics of combined defects is connected with certain difficulties due to practical absence of norms and criteria allowing to recognize them. In order to eliminate this problem, the article presents the results of a complex analysis of the values of diagnostic criteria used to recognize the type of defects based on the results of dissolved gas analysis for transformers in which discharges with different intensity accompanied by overheating with temperature of $150-300^{\circ} \mathrm{C}$ are detected.

Publication analysis and research agenda. Both analytical and graphical methods are used for defect type identification [1]. Analytical methods are based on the analysis of gas ratios characteristic of different defect types. For example in standards [2-6] the values of three gas ratios are regulated for defect type identification: $\mathrm{CH} 4 / \mathrm{H} 2, \mathrm{C} 2 \mathrm{H} 4 / \mathrm{C} 2 \mathrm{H} 6$ and $\mathrm{C} 2 \mathrm{H} 2 / \mathrm{C} 2 \mathrm{H} 4$. The Dörnenburg method [7] uses four ratios: $\mathrm{CH} 4 / \mathrm{H} 2, \mathrm{C} 2 \mathrm{H} 2 / \mathrm{C} 2 \mathrm{H} 4, \mathrm{C} 2 \mathrm{H} 2 / \mathrm{CH} 4$ and $\mathrm{C} 2 \mathrm{H} 6 / \mathrm{C} 2 \mathrm{H} 2$. The Rogers method [8] also uses four ratios: $\mathrm{CH} 4 / \mathrm{H} 2, \mathrm{C} 2 \mathrm{H} 6 / \mathrm{CH} 4, \mathrm{C} 2 \mathrm{H} 4 / \mathrm{C} 2 \mathrm{H} 6$ and $\mathrm{C} 2 \mathrm{H} 2 / \mathrm{C} 2 \mathrm{H} 4$. In contrast, 
the MSS method [9] uses five ratios: $\mathrm{H} 2 / \mathrm{CH} 4, \mathrm{C} 2 \mathrm{H} 4 / \mathrm{C} 2 \mathrm{H} 6, \mathrm{C} 2 \mathrm{H} 2 / \mathrm{C} 2 \mathrm{H} 6, \mathrm{C} 2 \mathrm{H} 4 / \mathrm{C} 3 \mathrm{H} 6$ and $\mathrm{CO} 2 / \mathrm{CO}$. However, of the eight standards analyzed only $[5,6]$ regulates values of gas ratios characteristic of combined defects. At the same time the given standards do not allow to estimate either the discharge energy or the hot spot temperature.

In turn, graphical recognition methods can use various criteria as coordinates of the object to be diagnosed. The values of the gas ratios are used in the ETRA square [10] and the graphical interpretation of the gas ratios according to [2]. In the Duval Triangles [11] and GATRON fault gas triangle [12], the defect type is determined by the gas percentage values (CH4, C2H4, C2H2 in the Duval method) and (H2, $\mathrm{C} 2 \mathrm{H} 2$ and weighted sum of hydrocarbon gases $\mathrm{CH} 4, \mathrm{C} 2 \mathrm{H} 4, \mathrm{C} 2 \mathrm{H} 6, \mathrm{C} 3 \mathrm{H} 6$ and $\mathrm{C} 3 \mathrm{H} 8$ in the GATRON method). In the Key Gas method [3] the type of defect is determined by the percentage content of the five gases $\mathrm{H} 2, \mathrm{CH} 4, \mathrm{C} 2 \mathrm{H} 6$, $\mathrm{C} 2 \mathrm{H} 4$ and $\mathrm{C} 2 \mathrm{H} 2$. In the Nomogram method $[10,13]$ the defect type is determined by a graphical image, which is plotted by the ratios of five gases $(\mathrm{H} 2, \mathrm{CH} 4, \mathrm{C} 2 \mathrm{H} 6, \mathrm{C} 2 \mathrm{H} 4$ and $\mathrm{C} 2 \mathrm{H} 2)$ to the gas with the maximum content. The type of defect is determined by comparing the obtained nomogram with the reference one. It should be noted that both in the ETRA square and in the Duval triangle, areas corresponding to combined defects are highlighted. However, in the ETRA square this area corresponds only to discharges and overheating with a temperature above $700^{\circ} \mathrm{C}$. In the Duval triangle, the region corresponding to the combined defects is related neither to the discharge energy nor to the hot spot temperature.

In addition to the norms and criteria regulated by known standards and author's methods, a rather large number of publications are nowadays devoted to the interpretation of DGA results using more advanced mathematical tools, such as artificial neural network (ANN) [14-15], fuzzy logic [16-17], Adaptive Neuro-Fuzzy Inference System (ANFIS) [18-19]. In [20], a modified clustering method has been proposed to classify the state of different transformers. In [21], Adaptive Dynamic Rose Guided Whale Optimization algorithm is used to improve the accuracy of transformer diagnosis using various classical diagnostic methods. A multi-nominal classification model called KosaNet based on decision trees is described in [22]. In [23], the diagnostic accuracy of power transformer faults is improved using K-Nearest Neighbors (KNN). A comparative analysis of dissolved gases using machine learning and traditional diagnostic methods has been carried out in [24].

However, despite the rather large number of publications, issues related to improving the recognition reliability of combined defects are not well covered, which is the reason for this article.

Analysis of the values of the diagnostic criteria used to recognize the type of defect in power transformers with discharges, which are accompanied by low-temperature overheating

As noted in [25], one of the significant problems encountered in determining the type of defect based on DGA results is that using different standards and diagnostic criteria (characteristic gas ratios, gas percentage content values, gas concentration ratios to the maximum gas concentration value) for the same data can lead to different diagnoses. One way to eliminate this problem is to evaluate and analyze the values of all diagnostic criteria simultaneously in the same type of equipment with defects of the same type, with subsequent training of the diagnostic model. The use of such an approach makes it possible, on the one hand, to eliminate contradictions between different diagnostic criteria when recognizing defects of the same type [26], and, on the other hand, to determine characteristic ranges of diagnostic criteria values for defects for which such ranges are not regulated [27-28].

As input data for analysis of diagnostic criteria values, which are used to determine the type of defect according to DGA results, the results of periodic tests on 135 power transformers were used, in which electrical discharges with different intensity which were accompanied by overheating with temperature of $150-300^{\circ} \mathrm{C}$ were identified. The raw data were first divided into several separate arrays depending on the type of defect detected. Then, by analogy with [26-28], the percentage content values for each of the five gases were determined, the values of 
characteristic gas ratios were calculated, and defect nomograms were constructed for each of the transformers analyses. The obtained values were compared with each other and if the value of at least one of the criteria differed significantly from those obtained earlier, the DGA results for the analyzed transformer were transferred to another array. The procedure of successive selection of homogeneous DGA results allowed the formation of 10 arrays with similar values of diagnostic criteria. The ranges of gas percentages in transformers with electrical discharges with different degrees of intensity, which were accompanied by overheating with a temperature of 150-300C, are shown in Table 1 (the symbol $\mathrm{N}$ indicates the volume of sample values for each of the arrays). As can be seen from Table 1, the gas percentage content of the 10 arrays obtained varies significantly. The gases with maximum content are $\mathrm{H} 2$ (arrays No. 1-8) and $\mathrm{C} 2 \mathrm{H} 2$ (arrays No. 9-10), indicating the presence of electrical discharges in the transformers under investigation. For almost all 10 arrays formed, the second gas in content is $\mathrm{C} 2 \mathrm{H} 6$, indicating the presence of low-temperature overheating. The content of $\mathrm{C} 2 \mathrm{H} 2$ increases as the discharge energy increases and in some transformers, according to the DGA results of which array No. 8 was formed, exceeds the content of C2H6.

The content of $\mathrm{CH} 4$ and $\mathrm{C} 2 \mathrm{H} 4$ varies mainly depending on the overheating temperature. In [30] it is shown that in overheating with temperatures of $150-300^{\circ} \mathrm{C}$ the gas with maximum content is $\mathrm{C} 2 \mathrm{H} 6$ and the second gas in content depending on the hot spot temperature is either $\mathrm{CH} 4$ or $\mathrm{C} 2 \mathrm{H} 4$. As the hot spot temperature increases, the percentage of $\mathrm{C} 2 \mathrm{H} 4$ increases. This trend is also true for combined defects, for example, in transformers whose DGA results formed arrays No. 4 and 5, the gas content has very similar values. The difference is that transformers with DGA results for array No. 4 have a higher $\mathrm{CH} 4$ content, while transformers with DGA results for array No. 5 have a higher $\mathrm{C} 2 \mathrm{H} 4$ content.

Comparing the gas percentage ranges given in Table 1 with the gas percentage ranges regulated by the Key Gas Method [31], it should be noted that the values obtained do not correspond to the gas percentage values for any of the defect types recognizable by the Key Gas Method.

Table 1. Gas percentage in high-voltage power transformers with electrical discharges with different intensity, which were accompanied by overheating with temperatures of $150-300^{\circ} \mathrm{C}$

\begin{tabular}{|c|c|c|c|c|c|c|}
\hline \multirow{2}{*}{ Array } & Type of defect, sample volume & \multicolumn{5}{c|}{ Gas percentage, $\%$} \\
\cline { 3 - 7 } & & $\mathrm{H} 2$ & $\mathrm{CH} 4$ & $\mathrm{C} 2 \mathrm{H} 6$ & $\mathrm{C} 2 \mathrm{H} 4$ & $\mathrm{C} 2 \mathrm{H} 2$ \\
\hline 1 & Partial discharges and low-temperature overheating. N=20. & $73-99$ & $0.2-7.5$ & $0.48-17$ & $0-5.3$ & $0-1.58$ \\
\hline 2 & Partial discharges and low-temperature overheating. N=6. & $81-96$ & $1-6.5$ & $1.6-10$ & $1.1-4.5$ & $0-1.6$ \\
\hline 3 & Discharges and low-temperature overheating. $\mathrm{N}=22$. & $38-73$ & $0.002-10$ & $15-47$ & $0.002-18$ & $0-3$ \\
\hline 4 & Discharges and low-temperature overheating. $\mathrm{N}=20$. & $38-73$ & $10-28$ & $13-35$ & $0.04-11$ & $0-2.1$ \\
\hline 5 & Discharges and low-temperature overheating. $\mathrm{N}=6$. & $33-66$ & $1-10$ & $14-35$ & $10-28$ & $0-5$ \\
\hline 6 & Discharges and low-temperature overheating. $\mathrm{N}=5$. & $30-41$ & $3-22$ & $23-40.5$ & $6-20$ & $2.9-10$ \\
\hline 7 & Discharges and low-temperature overheating. N=7. & $40-68$ & $4-22$ & $15-30$ & $1-17$ & $1.6-17$ \\
\hline 8 & $\begin{array}{c}\text { Discharges with high energy density and overheating with } \\
\text { temperatures of } 150-300^{\circ} \mathrm{C} \text {. N=24. }\end{array}$ & $27-74$ & $3-17$ & $6-28$ & $0.4-15$ & $8-37$ \\
\hline 9 & $\begin{array}{c}\text { Discharges with high energy density and overheating with } \\
\text { temperatures of } 150-300^{\circ} \mathrm{C} \text {. N=9. }\end{array}$ & $1.5-6.5$ & $1.7-10$ & $23-35$ & $14-22$ & $36-51$ \\
\hline 10 & $\begin{array}{c}\text { Discharges with high energy density and overheating with } \\
\text { temperatures of } 150-300^{\circ} \mathrm{C} \text {. N=16. }\end{array}$ & $5-37$ & $1.5-21$ & $2.5-36$ & $0.6-22$ & $25-58$ \\
\hline
\end{tabular}

As can be seen from Table 2, for 9 out of 10 arrays (No. 1-8 and 10), the content of H2 exceeds the content of $\mathrm{CH} 4$, that is, the value of $\mathrm{CH} 4 / \mathrm{H} 2<1$, which is more typical of the electrical type defects. At the same time for the transformers in which the partial discharges accompanied by overheating with temperature $150-300^{\circ} \mathrm{C}$ have been revealed, values of $\mathrm{CH} 4 / \mathrm{H} 2<0.1$. For the transformers with discharges with higher energy density accompanied by overheating with temperature $150-300^{\circ} \mathrm{C}$, values of the ratio $0.1<\mathrm{CH} 4 / \mathrm{H} 2<1$. Only in transformers, according to the DGA results of which the array No. 9 is formed, the CH4 content 
exceeds the $\mathrm{H} 2$ content, that is the value of the ratio $\mathrm{CH} 4 / \mathrm{H} 2>1$, which is more typical for the thermal type defects.

The ranges of characteristic gas ratios obtained from the DGA results of the transformers analyzed are given in Table 2. The studies performed in [29] showed that the defect nomograms constructed by the DGA results of the same type of equipment, with a defect of the same nature can differ significantly. In order to account for drift in the coordinate values of defect nomograms (values of ratios of gas concentrations to the gas with the maximum content), defect nomograms, by analogy with [26-28], were represented in the form of graphical areas instead of defect nomograms. Graphical areas based on the DGA results of transformers where electrical discharges with different intensity, which were accompanied by overheating with temperature of $150-300^{\circ} \mathrm{C}$ were detected, are shown in Fig. 1 . The number of the graphic area coincides with the number of defects from Tables I and II. Dotted lines in the figures mark upper and lower boundaries of areas, solid line marks centres of areas which coincide with defect nomograms.

For all the analyzed transformers the values of the ratio $\mathrm{C} 2 \mathrm{H} 6 / \mathrm{CH} 4>1$, which according to Rogers [8] is typical only for low-temperature overheating, but as can be seen from Table 2, the same values of this ratio take place and in discharges, which are accompanied by overheating with temperature $150-300^{\circ} \mathrm{C}$.

Table 2.

Gas ratio values in high-voltage power transformers with electrical discharges with different intensity, which were accompanied by overheating with temperatures of $150-300^{\circ} \mathrm{C}$

\begin{tabular}{|c|c|c|c|c|c|c|}
\hline \multirow{2}{*}{ Array } & \multicolumn{7}{|c|}{ Gas ratio values } \\
\cline { 2 - 7 } & $\mathrm{CH} 4 / \mathrm{H} 2$ & $\mathrm{C} 2 \mathrm{H} 6 / \mathrm{CH} 4$ & $\mathrm{C} 2 \mathrm{H} 4 / \mathrm{C} 2 \mathrm{H} 6$ & $\mathrm{C} 2 \mathrm{H} 2 / \mathrm{CH} 4$ & $\mathrm{C} 2 \mathrm{H} 2 / \mathrm{C} 2 \mathrm{H} 6$ & $\mathrm{C} 2 \mathrm{H} 2 / \mathrm{C} 2 \mathrm{H} 4$ \\
\hline 1 & $0.032-0.09$ & $1.5-4.1$ & $0.01-0.58$ & - & - & - \\
\hline 2 & $0.011-0.073$ & $1.1-2.0$ & $0.35-0.92$ & $0.087-0.208$ & $0.07-0.139$ & $0.12-0.16$ \\
\hline 3 & $0.0004-0.19$ & $4.2-800$ & $0.125-0.46$ & $0.1-0.143$ & $0.0001-0.06$ & $0.001-0.27$ \\
\hline 4 & $0.19-0.72$ & $1.06-2.9$ & $0.007-0.373$ & $0.007-0.07$ & $0.004-0.039$ & $0.039-0.56$ \\
\hline 5 & $0.08-0.147$ & $1.6-11.2$ & $0.71-0.85$ & - & - & - \\
\hline 6 & $0.5-0.6$ & $1.2-1.5$ & $0.6-0.63$ & $0.33-0.43$ & $0.23-0.36$ & $0.5-0.58$ \\
\hline 7 & $0.1-0.46$ & $1.1-2.5$ & $0.05-0.7$ & $0.07-1.5$ & $0.06-0.62$ & $0.88-1.1$ \\
\hline 8 & $0.1-0.38$ & $1.03-3.8$ & $0.07-0.66$ & $0.99-6.0$ & $0.47-5.1$ & $1.67-68$ \\
\hline 9 & $1.1-2.1$ & $2.7-6.3$ & $0.42-0.93$ & $4.5-9.3$ & $1.05-2.2$ & $1.9-3.33$ \\
\hline 10 & $0.43-0.92$ & $1.09-6.2$ & $0.01-1.0$ & $1.7-12$ & $1.04-4.6$ & $1.3-66$ \\
\hline
\end{tabular}

Value of $\mathrm{C} 2 \mathrm{H} 4 / \mathrm{C} 2 \mathrm{H} 6$ ratio in all data sets does not exceed 1 that indicates lowtemperature character of overheating. At the same time, relatively high values of this ratio are observed both for partial discharges with low-temperature overheating (array No. 2), and for discharges with low energy density and low-temperature overheating (array No. 5), as well as for discharges with high energy density and low-temperature overheating (arrays No. 9 and 10). This fact made it possible to conclude that for the analyzed defects the value of $\mathrm{C} 2 \mathrm{H} 4 / \mathrm{C} 2 \mathrm{H} 6$ ratio is determined more by the hot spot temperature than by the discharge energy. At the same time, the values of $\mathrm{C} 2 \mathrm{H} 2 / \mathrm{CH} 4, \mathrm{C} 2 \mathrm{H} 2 / \mathrm{C} 2 \mathrm{H} 6$ and $\mathrm{C} 2 \mathrm{H} 2 / \mathrm{C} 2 \mathrm{H} 4$ increase with the growth of the discharge energy, which allows to conclude that the values of these ratios are determined by the discharge energy. Thus, in discharge transformers with low-temperature overheating, the values of $\mathrm{CH} 4 / \mathrm{H} 2, \mathrm{C} 2 \mathrm{H} 2 / \mathrm{CH} 4, \mathrm{C} 2 \mathrm{H} 2 / \mathrm{C} 2 \mathrm{H} 6$ and $\mathrm{C} 2 \mathrm{H} 2 / \mathrm{C} 2 \mathrm{H} 4$ determine the discharge energy in accordance with the norms regulated in the most known standards [2, 4-6], the value of $\mathrm{C} 2 \mathrm{H} 4 / \mathrm{C} 2 \mathrm{H} 6$ slightly varies depending on hot spot temperature and the value of $\mathrm{C} 2 \mathrm{H} 6 / \mathrm{CH} 4>1$. The graphical areas in Figure 1 also show this trend.

As can be seen from Figure 1, for all graphical areas without exception there is a characteristic "triangle" with the apex corresponding to the values of $\mathrm{C} 2 \mathrm{H} 6$. The analysis showed 
that in none of the existing standards similar defect nomograms (centres of reference areas, highlighted in solid lines in the figures) are not regulated. Some of the areas shown have been given in [26, 32, 33 and 34].

However, despite this, it would be desirable to be able to determine the defect type of equipment without the presence of a similar reference nomogram or a nomogram obtained by other researchers. As shown in [27], the nomograms obtained from the DGA results for transformers with combined defects are the sum of the nomogram corresponding to the electric discharge of a certain intensity and the nomogram corresponding to the thermal defect with a certain temperature. Figure 2 illustrates this fact.

In order to recognize combined defects using the Nomogram method, the coordinates of a known nomogram corresponding to the closest discharge or closest heating must be subtracted from the coordinates of the nomogram to be analyzed. The nomogram obtained as a result of the subtraction will determine either the thermal or electrical defect type.

Analysis of the dynamics of gas content change during the development of discharges with different intensity, which are accompanied by overheating with temperatures of $150-300^{\circ} \mathrm{C}$.

One possible way of early detection of developing defects in oil-filled equipment, based on the DGA results, is to analyze the dynamics of change in diagnostic criteria over time during the development of the defect. As shown in [36], this kind of analysis is best carried out using defect nomograms. The analysis made it possible to establish that during the development of discharges with different intensity, which are accompanied by overheating in the low temperature range, in most cases it is the discharges that are the primary defect. Overheating occurs already in the process of discharge development.
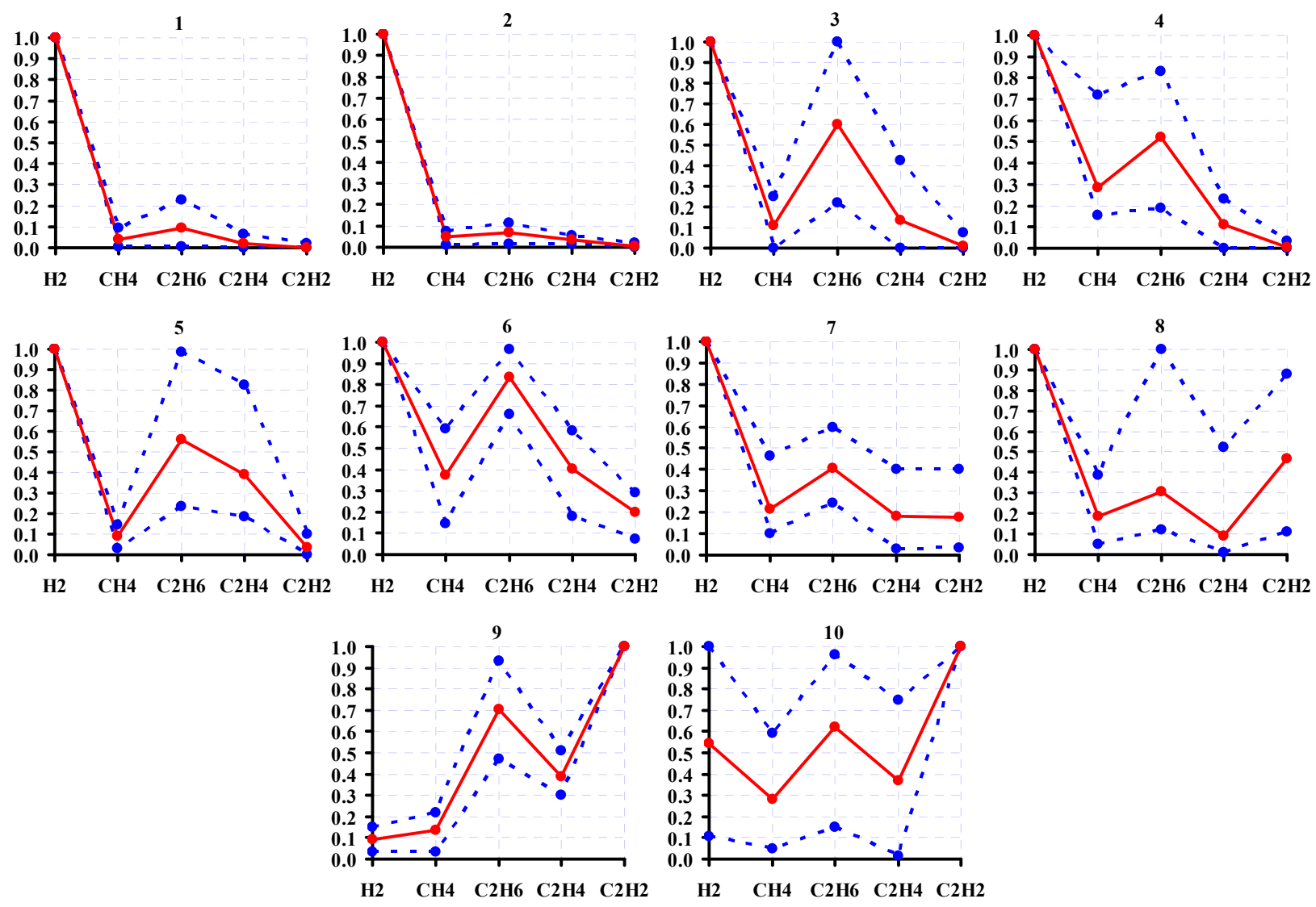

Figure 1. Graphical areas based on DGA results for high voltage power transformers with electrical discharges with different intensity, which were accompanied by overheating with temperatures of 150-

$300^{\circ} \mathrm{C}$ 
As can be seen from the figure, the defect nomograms plotted from the first two tests correspond to discharges with low energy density. However, during the development process (nomograms No. 3 and 4), in addition to partial discharges, low-temperature overheating caused by increased heating of the bolted joints occurred in this transformer.

As an example, Figure 3 shows the evolution of nomograms during the development of low energy density partial discharges accompanied by low-temperature overheating, plotted from the DGA results of a transformer with a rated capacity of 40 MVA and a voltage of $110 \mathrm{kV}$. As can be seen from the figure, the defect in the transformer in question initially started as low energy density discharges (nomogram No. 1). However, the defect nomograms constructed from the results of two subsequent tests correspond to arc discharges, which indicates an increase in discharge energy during the development of the defect. Only the nomogram based on the DGA results, obtained just before the transformer was repaired, corresponds to discharges with high energy density, which are accompanied by low-temperature overheating.

Figure 4 shows the evolution of defect nomograms in a transformer with a rated capacity of $250 \mathrm{MVA}$ and a voltage of $220 \mathrm{kV}$ during the development of discharges with high energy density, which are accompanied by a low-temperature overheating.

Assessment of the recognition reliability of discharges that are accompanied by overheating with temperatures of $150-300^{\circ} \mathrm{C}$ using known standards and techniques. As the results of the analysis given in [26,32-34] have shown, the recognition of discharges that are accompanied by low-temperature overheating, using the norms and criteria regulated by the current standards and author's methods, does not always allow a correct diagnosis. Moreover, often the same DGA results are interpreted differently in different sources. For example, the same DGA results: $\mathrm{H} 2=0.012 \%$ vol.; $\quad \mathrm{CH} 4=0.0017 \%$ vol.; $\quad \mathrm{C} 2 \mathrm{H} 6=0.0032 \%$ vol.; $\mathrm{C} 2 \mathrm{H} 4=0.0023 \%$ vol. and $\mathrm{C} 2 \mathrm{H} 2=0.0004 \%$ vol. in [37] are interpreted as partial discharges, while in [38] - as a low-temperature overheating. It is therefore of practical interest to assess the reliability of the recognition of discharges which are accompanied by low-temperature overheating, using the best known standards and techniques. Using the approach given in [26$28]$, in the process of analysis it was determined the statistics of correct diagnoses, partially correct diagnoses (the type of defect was determined correctly, but its intensity - temperature of heating or energy density of discharge - was estimated incorrectly). The statistics of incorrect diagnoses and failures of recognition (that is cases where the analyzed method does not allow to establish a diagnosis) were also recorded. The results of the analysis are shown in Table 3 . As in [26-28], the numerator of column 1 is the percentage of correct diagnoses and the denominator is the percentage of partially correct diagnoses. The numerator of column 2 is the percentage of incorrect diagnoses and the denominator is the percentage of recognition failures. Figure 5 shows the results of the diagnostics of the analyzed transformers using the graphical representation of the gas ratios according to IEC 60599 (Fig. 5 a), the Duval triangle (Fig. 5 b) and the ETRA square (Fig. 5 c). When analyzing the data in Table 3 it is easy to see that the recognition reliability of the analyzed defects, using the norms and criteria regulated by the different standards, differs significantly. The highest number of correct diagnoses (up to $15 \%$ ) is provided by the use of ratio values regulated in [5]. Approximately $7 \%$ of correct diagnoses can be established using the Duval triangle. The highest number of partially correct diagnoses was obtained using the ETRA square (41\%), and the Duval triangle (30\%). At the same time, the highest number of failures of recognition are observed for methods based on gas ratios $(84.4 \%$ for MSS, $81.5 \%$ for IEC 60599 , $80 \%$ for Dörnenburg, $74.8 \%$ for Rogers, $59.3 \%$ for SOU, and $45.2 \%$ for RD).

As can be seen from Table 3 , the use of the gas ratios values, regulated by the standards $[2,4-5]$, in relation to the recognition of discharges with different intensity, which are accompanied by overheating with a temperature of $150-300^{\circ} \mathrm{C}$, allowed to put partially correct diagnosis only for transformers, the DGA results of which formed array No. 1. In all other cases, a failure of recognition was recorded. 

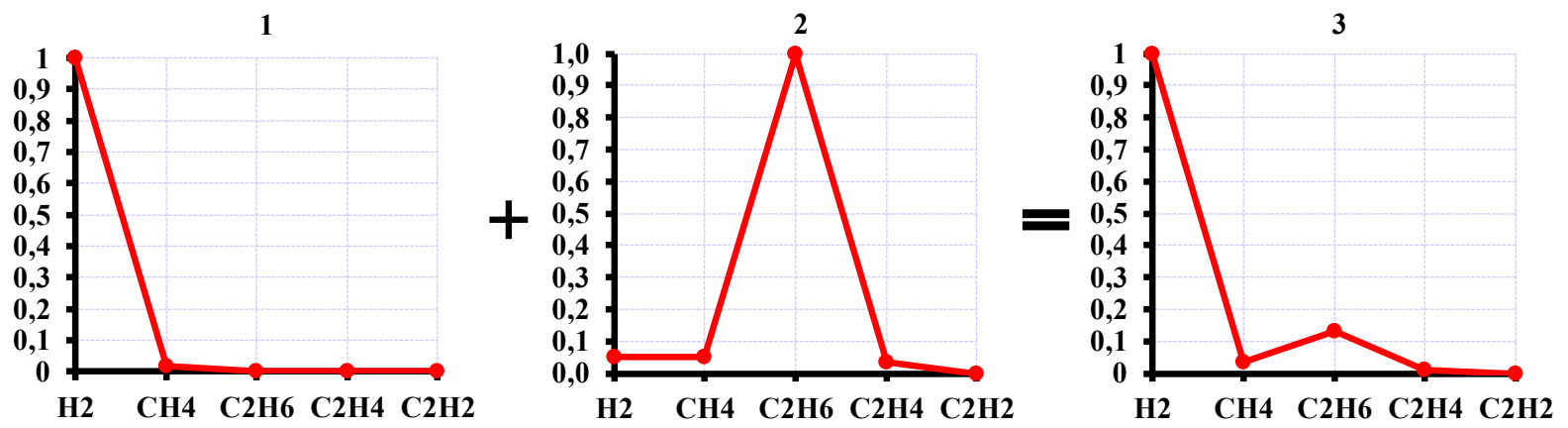

4
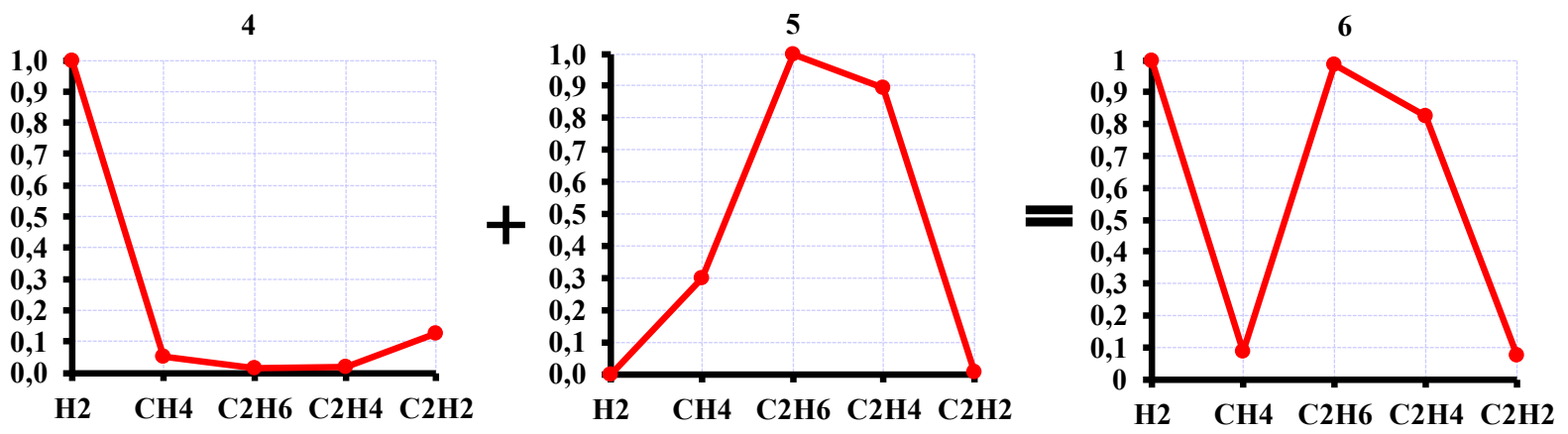

7
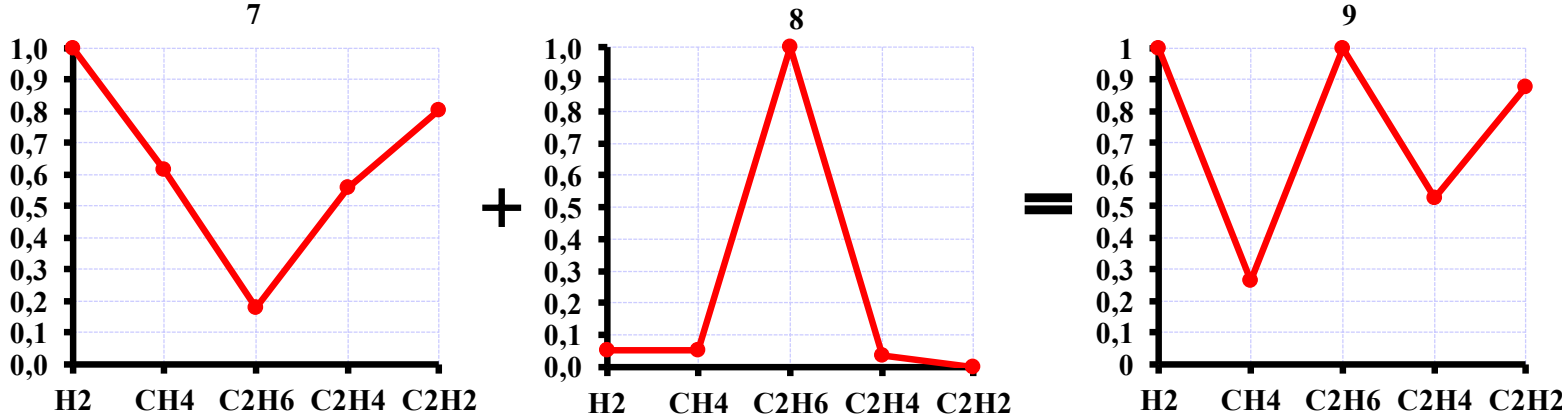

Figure 2. Scheme of formation of combined defect nomograms (electrical discharges, which are accompanied by low-temperature overheating) from known thermal and electrical defect nomograms:

1 - partial discharges; 2, 5 and 8 - overheating with temperature $150-300^{\circ} \mathrm{C} ; 3$ - partial discharges accompanied by overheating with temperature $150-300^{\circ} \mathrm{C} ; 4$ - discharges with low

energy density; 6 - discharges with low energy density accompanied by overheating with temperature $150-300^{\circ} \mathrm{C} ; 7$ - arc discharges; 9 - arc discharges accompanied by overheating with temperature $150-300^{\circ} \mathrm{C}$.
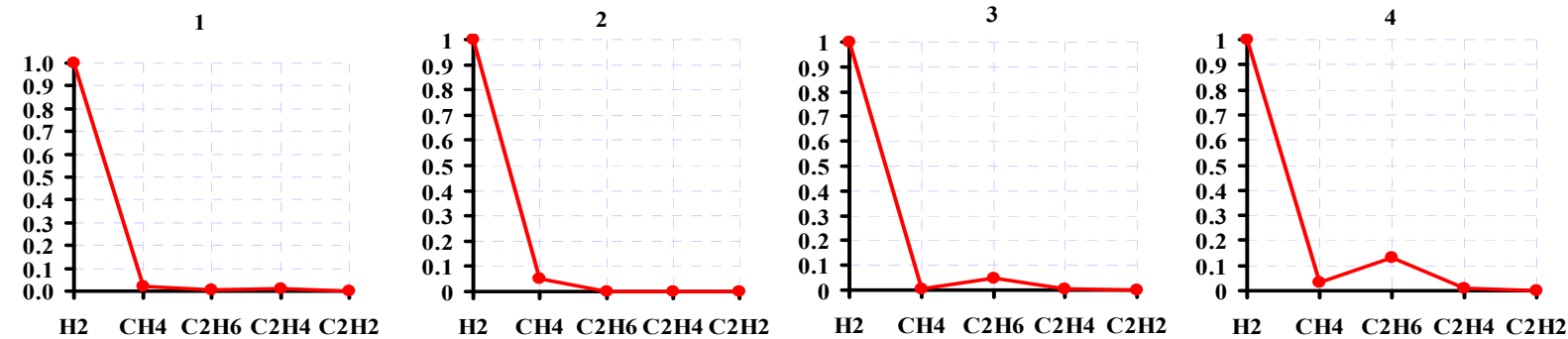

Figure 3. The evolution of defect nomograms in a transformer with a rated capacity of 40 MVA and a voltage of $110 \mathrm{kV}$ during the development of low energy density partial discharges, which are accompanied by low-temperature overheating

The main reason for the failure of recognition is that, according to these standards, the values of the $\mathrm{C} 2 \mathrm{H} 4 / \mathrm{C} 2 \mathrm{H} 6$ ratio for low and high energy density discharges are regulated at a level greater than 1 (Fig.5a). 




H2 $\mathrm{CH} 4$ C2H6 C2H4 C2H2

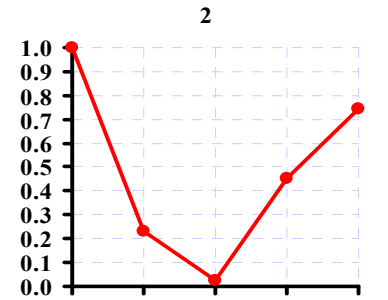

$\mathrm{H} 2 \mathrm{CH}_{4} \mathrm{C} 2 \mathrm{H} 6 \mathrm{C} 2 \mathrm{H} 4 \mathrm{C} 2 \mathrm{H} 2$
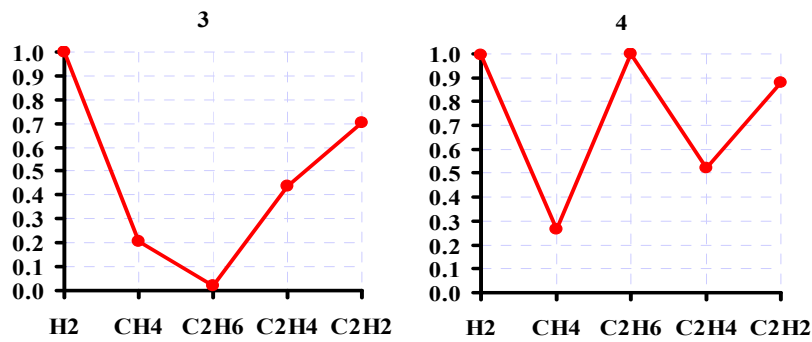

Figure 4. The evolution of defect nomograms in a transformer with a rated capacity of 250 MVA and a voltage of $220 \mathrm{kV}$ during the development of discharges with high energy density, which are accompanied by low-temperature overheating

Table 3.

Results of a comparative analysis of the recognition reliability of discharges that are accompanied by low-temperature overheating using the best known standards and techniques

\begin{tabular}{|c|c|c|c|c|c|c|c|c|c|c|c|c|c|c|c|c|c|c|}
\hline \multirow[t]{2}{*}{ 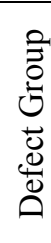 } & \multicolumn{2}{|c|}{  } & \multicolumn{2}{|c|}{  } & \multicolumn{2}{|c|}{ 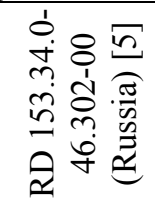 } & \multicolumn{2}{|c|}{ 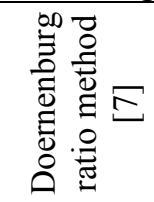 } & \multicolumn{2}{|c|}{ 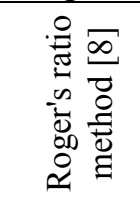 } & \multicolumn{2}{|c|}{ 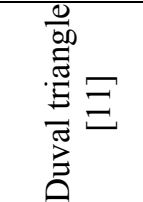 } & \multicolumn{2}{|c|}{ 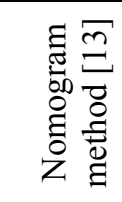 } & \multicolumn{2}{|c|}{  } & \multicolumn{2}{|c|}{$\begin{array}{l}a \\
\tilde{a} \\
\sum \\
\sum\end{array}$} \\
\hline & 1 & 2 & 1 & 2 & 1 & 2 & 1 & 2 & 1 & 2 & 1 & 2 & 1 & 2 & 1 & 2 & 1 & 2 \\
\hline \multirow{2}{*}{1} & - & - & - & - & - & - & - & - & - & - & - & 90 & - & - & - & - & - & - \\
\hline & 60 & 40 & 60 & 40 & 85 & 15 & 50 & 50 & - & 100 & 10 & - & - & 100 & 100 & - & 75 & 25 \\
\hline \multirow{2}{*}{2} & - & - & - & - & - & - & - & - & - & - & 17 & 83 & - & - & - & - & - & - \\
\hline & - & 100 & - & 100 & 17 & 83 & 100 & - & - & 100 & - & - & - & 100 & 100 & - & - & 100 \\
\hline \multirow{2}{*}{3} & - & 23 & - & 59 & - & 68 & - & 9 & - & - & 9 & 77 & - & - & - & 27 & - & 23 \\
\hline & - & 77 & - & 41 & - & 32 & - & 91 & - & 100 & 14 & - & - & 100 & 73 & - & - & 23 \\
\hline \multirow{2}{*}{4} & - & - & - & 40 & - & 80 & - & - & - & - & 15 & 55 & - & - & - & 35 & - & 85 \\
\hline & - & 100 & - & 60 & - & 20 & - & 100 & 5 & 95 & 30 & - & - & 100 & 60 & 5 & - & 100 \\
\hline \multirow{2}{*}{5} & - & - & - & - & - & 67 & - & - & - & - & 17 & 83 & - & - & - & 67 & - & - \\
\hline & - & 100 & - & 100 & - & 33 & - & 100 & - & 100 & - & - & - & 100 & 33 & - & - & 100 \\
\hline \multirow{2}{*}{6} & - & - & - & - & 40 & - & - & - & - & - & 40 & 40 & - & - & - & 100 & - & - \\
\hline & - & 100 & - & 100 & - & 60 & - & 100 & - & 100 & 20 & - & - & 100 & - & - & - & 100 \\
\hline \multirow{2}{*}{7} & - & - & - & 14 & - & - & - & - & - & - & 14 & 86 & - & - & - & 100 & - & - \\
\hline & - & 100 & - & 86 & - & 100 & - & 100 & - & 100 & - & - & - & 100 & - & - & - & 100 \\
\hline \multirow{2}{*}{8} & - & - & - & 42 & - & - & - & - & - & - & - & 21 & - & - & - & 100 & - & - \\
\hline & - & 100 & - & 58 & - & 100 & 21 & 79 & 67 & 33 & 79 & - & - & 100 & - & - & - & 100 \\
\hline \multirow[t]{2}{*}{9} & - & - & - & - & 100 & - & - & - & - & - & - & 89 & - & - & - & 100 & - & - \\
\hline & 89 & 11 & 89 & 11 & - & - & - & 100 & 89 & 11 & 11 & - & - & 100 & - & - & - & 100 \\
\hline \multirow{2}{*}{10} & - & - & - & 13 & 56 & 6 & - & - & - & - & - & 44 & - & - & - & 94 & 6 & - \\
\hline & - & 100 & 6 & 81 & - & 38 & 25 & 75 & 56 & 44 & 56 & - & - & 100 & - & 6 & - & 94 \\
\hline \multirow{2}{*}{$\Sigma$} & - & 4 & - & 25 & 15 & 27 & - & 1 & - & - & 7 & 62 & - & - & - & 57 & 1 & 4 \\
\hline & 15 & 81 & 16 & 59 & 13 & 45 & 19 & 80 & 25 & 75 & 30 & - & - & 100 & 41 & 1 & 11 & 84 \\
\hline
\end{tabular}

At the same time, because of the development of low-temperature overheating, C2H6 is the second gas with the highest content (Table 1) and, therefore, regardless of the discharge energy, C2H4/C2H6 ratio value is less than 1 (Table 2). As can be seen from Table 3 and Figure $5 \mathrm{~b}$ the use of the Duval triangle allows a partially correct diagnosis of the discharge energy for $30 \%$ of all transformers analyzed, but the presence of overheating was recognized for only $7 \%$ of the sample analyzed. In fact, the lack of account of the $\mathrm{C} 2 \mathrm{H} 6$ concentration in the analyzed triangle did not allow a correct diagnosis for $93 \%$ of the transformers. The incorrect diagnoses in the diagnostics of discharges with different intensity, which are accompanied by overheating with a temperature of $150-300^{\circ} \mathrm{C}$, using the ETRA square, are due to the absence in this method of defect areas corresponding to discharges and low-temperature overheating, as can be easily seen by analyzing Fig. 5 c. Since none of the given defect nomograms are regulated by known standards, the use of the Nomogram method for all 10 defect types resulted in a failure of 
recognition. Thus, the greatest reliability in recognition of discharges with different intensity, which are accompanied by overheating with temperature of $150-300^{\circ} \mathrm{C}$, is provided by graphic methods of interpretation (ETRA square and Duval triangle), which allow to partially recognize the presence of discharges, as well as their energy. At the same time, diagnosis using analytical methods based on the use of gas ratios gives much worse results, because most of the standards used do not contain the values of gas ratios corresponding to the defect in question. Therefore, the values of gas ratios obtained in Table 2 will significantly increase the reliability of recognition of discharges, which are accompanied by low-temperature overheating.
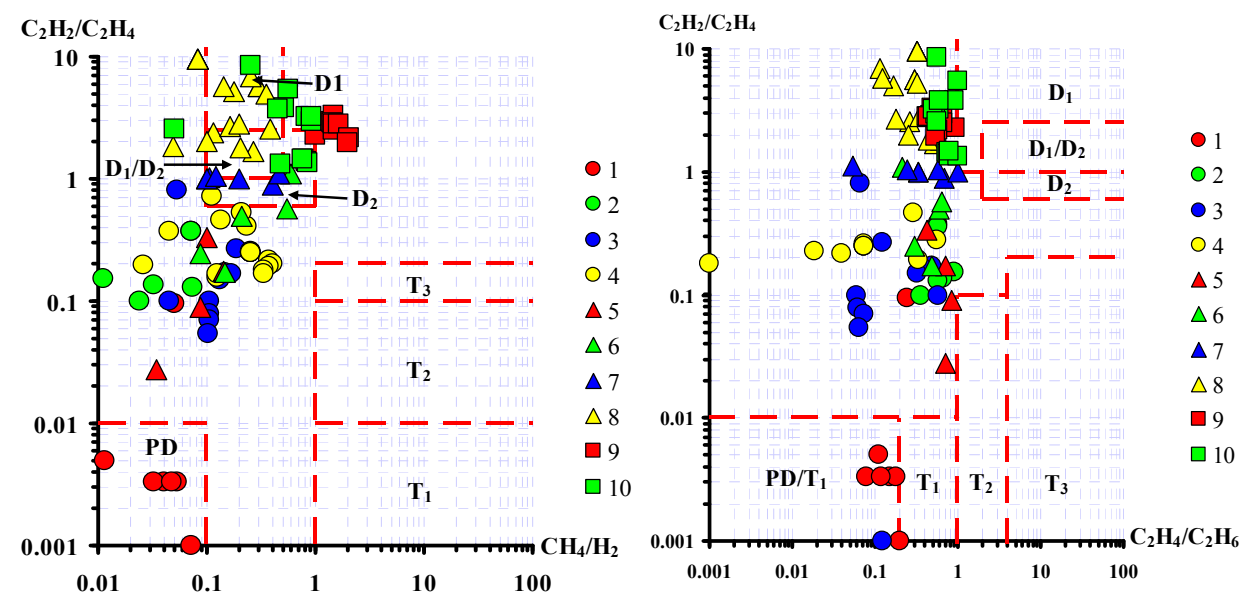

a

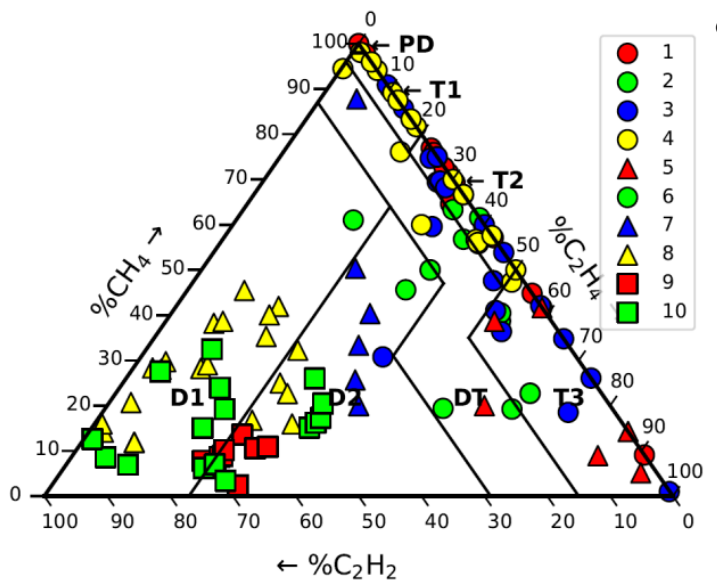

$\mathrm{b}$

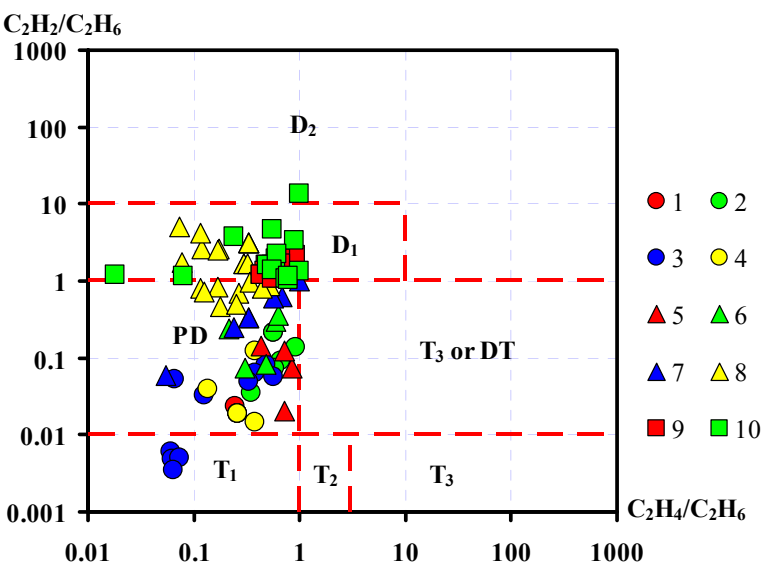

c

Figure 5. Diagnostic results for transformers with discharges with different intensity accompanied by overheating with temperatures of $150-300^{\circ} \mathrm{C}$ using the IEC 60599 graphical method (a), Duval triangle (b), and the ETRA square (c).

Conclusions. The analysis of gas percentages, gas ratios and defect nomograms for 135 high-voltage transformers, where discharges with different intensity, which are accompanied by overheating with temperature of $150-300^{\circ} \mathrm{C}$ have been identified, allowed to establish that depending on discharge energy both gas percentages, gas ratios as well as defect graphical areas differ significantly. For all defects without exception the gases with the maximum content are $\mathrm{H} 2$ or $\mathrm{C} 2 \mathrm{H} 2$, and the second gas is $\mathrm{C} 2 \mathrm{H} 6$. From the analysis of gas ratios values for transformers with discharges with different intensity, which are accompanied by low-temperature overheating, it has been established that the values of $\mathrm{CH} 4 / \mathrm{H} 2, \mathrm{C} 2 \mathrm{H} 2 / \mathrm{CH} 4, \mathrm{C} 2 \mathrm{H} 2 / \mathrm{C} 2 \mathrm{H} 6$ and $\mathrm{C} 2 \mathrm{H} 2 / \mathrm{C} 2 \mathrm{H} 4$ ratios determine the discharge energy in accordance with the norms regulated in the most known standards, the $\mathrm{C} 2 \mathrm{H} 4 / \mathrm{C} 2 \mathrm{H} 6$ ratio value slightly varies depending on hot spot temperature, but does not exceed 1 , and the $\mathrm{C} 2 \mathrm{H} 6 / \mathrm{CH} 4>1$. 
Based on the analysis of the dynamics of changes in defect nomograms it was found that during the development of discharges with different intensity, which are accompanied by lowtemperature overheating, in most cases the primary defect is the discharge, and overheating occurs already in the process of their development. The performed analysis of recognition reliability of discharges with different intensity, which are accompanied by overheating with temperature $150-300^{\circ} \mathrm{C}$, with use of norms and criteria regulated by the most known standards and methods, showed that the greatest reliability in recognition of discharges with different intensity, which are accompanied by overheating with temperature of $150-300^{\circ} \mathrm{C}$, is provided by graphic methods of interpretation (ETRA square and Duval triangle), which allow to partially recognize the presence of discharges, as well as their energy. At the same time, diagnosis using analytical methods based on the use of gas ratios gives much worse results, because most of the standards used do not contain the values of gas ratios corresponding to the defect in question.

The ranges of gas percentages and ratios obtained and the plotted defect areas will significantly increase the reliability of detecting discharges with different intensity, which are accompanied by low-temperature overheating.

\section{Список використаної літератури:}

1.Kulyk, O. Analysis of the diagnostic criteria used to defect type recognition based on the results of analysis of gases dissolved in oil // Bulletin of the National Technical University "KhPI". Series: Energy: Reliability and Energy Efficiency. - 2020. - No. 1. - P. 15-25. - DOI: https://doi.org/10.20998/2224-0349.2020.01

2.Mineral oil-filled electrical equipment in service - Guidance on the interpretation of dissolved and free gases analysis: IEC 60599:2015. - Geneva, Switzerland: International Electrotechnical Commission, 2015. - 78 p.

3.IEEE Guide for the Interpretation of Gases Generated in Mineral Oil-Immersed Transformers: IEEE Std C57.104-2019. - Piscataway, NJ, USA: Institute of Electrical and Electronics Engineers, 2019. - 98 p.

4.Діагностика маслонаповненого трансформаторного обладнання за результатами хроматографічного аналізу вільних газів, відібраних із газового реле, і газів, розчинених у ізоляційному маслі. Методичні вказівки: СОУ-Н ЕЕ 46.501:2006. - Київ: Міністерство палива та енергетики України, 2007. $-91 \mathrm{c}$.

5.Методические указания по диагностике развивающихся дефектов трансформаторного оборудования по результатам хроматографического анализа газов, растворенных в масле: РД 153-34.046.302-00. - Москва: НЦ ЭНАС, 2001. - 41 с.

6.Методические указания по техническому диагностированию развивающихся дефектов маслонаполненного высоковольтного электрооборудования по результатам анализа газов, растворенных в минеральном трансформаторном масле: СТО 34.01-23-003-2019. - ПАО «Россети», 2019. - 63 с.

7.Dornenburg, E., Strittmater, W. Monitoring Oil-Cooled Transformers by Gas Analysis // Brown Boveri Review. - 1974. - Vol. 61. - P. 238-274.

8.Rogers, R. IEEE and IEC Codes to Interpret Incipient faults in Transformers, Using Gas in Oil Analysis // IEEE Trans. on Electrical Insulation. - 1978. - Vol. 5, No. 38. - P. 349-354. - DOI: https://doi.org/10.1109/TEI.1978.298141

9.Müller, R., Schliesing, H., Soldner, K. Die Beurteilung des Betriebszustandes von Transformatoren durch Gasanalyse // Elektrizitätswirtschaft. - 1977. - No. 76. - P. 345-349.

10.Guideline for the refurbishment of electric power transformers // Electric Technology Research Association. - 2009. - Vol. 65. - No. 1 (in Japanese).

11.Duval, M. The Duval Triangle for load tap changers non-mineral oils and low temperature faults in transformers // IEEE Electrical Insulation Magazine. - 2008. - Vol. 24, No. 6. - P. 22-29. - DOI: https://doi.org/10.1109/MEI.2008.4665347

12.Bräsel, E. Universal Fault Gas Triangle for Transformer Diagnostics. - GATRON GmbH. - P. 1-6.

13.Kawamura, T., Kawada, H., Ando, K., Yamaoka, M., Maeda, T., Takatsu, T. Analyzing gases dissolved in oil and its application to maintenance of transformers // Paris, SIGRE Session Report 12-05, $1986-5 \mathrm{p}$.

14. Naganathan, G. et al. Internal fault diagnosis of power transformer using artificial neural network // Materials Today: Proceedings. - 2021. - Vol. 2021. - DOI: https://doi.org/10.1016/j.matpr.2021.02.206

15.Ahmadi, S.-A., Sanaye-Pasand, M. A Robust Multi-Layer Framework for Online Condition Assessment of Power Transformers // IEEE Transactions on Power Delivery. - 2021. - DOI: https://doi.org/10.1109/TPWRD.2021.3074545

16.Genc, S., Karagol, S. Fuzzy Logic Application in DGA Methods to Classify Fault Type in Power Transformer // 2020 International Congress on Human-Computer Interaction, Optimization and Robotic Applications (HORA). - 2020. - P. 1-4. - DOI: https://doi.org/10.1109/HORA49412.2020.9152896 
17.Apte, R., Wajirabadkar, A. Incipient Fault Diagnosis of Transformer by DGA Using Fuzzy Logic // 2018 IEEE International Conference on Power Electronics, Drives and Energy Systems (PEDES). - 2018. - P. 1-5. - DOI: https://doi.org/10.1109/PEDES.2018.8707928.

18.Kari ,T. et al An integrated method of ANFIS and Dempster-Shafer theory for fault diagnosis of power transformer // IEEE Transactions on Dielectrics and Electrical Insulation. - 2018. - Vol. 25, No. 1. - P. 360-371. DOI: https://doi.org/10.1109/TDEI.2018.006746

19.Tightiz, L. et al. An intelligent system based on optimized ANFIS and association rules for power transformer fault diagnosis // ISA Transactions. - 2020. - Vol. 103. - P. 63-74. - DOI: https://doi.org/https://doi.org/10.1016/j.isatra.

20.Dias, L. et al. An unsupervised approach for fault diagnosis of power transformers // Quality and Reliability Engineering International. - 2021. - DOI: https://doi.org/10.1002/qre.2892.

21.Ghoneim, S. S. M., Farrag, T. A., Rashed, A. A., El-Kenawy, E.-S. M., Ibrahim, A., Adaptive Dynamic Meta-Heuristics for Feature Selection and Classification in Diagnostic Accuracy of Transformer Faults // IEEE Access. - 2021. - Vol. 9. - P. 78324-78340. - DOI: https://doi.org/10.1109/ACCESS.2021.3083593

22.Odongo, G., Musabe, R., Hanyurwimfura, D. A Multinomial DGA Classifier for Incipient Fault Detection in Oil-Impregnated Power Transformers // Algorithms. - 2021. - Vol. 14, No. 4. - P. 128. - DOI: http://dx.doi.org/10.3390/a14040128

23.Kherif, O., Benmahamed, Y., Teguar, M., Boubakeur, A., Ghoneim, S. S. M. Accuracy Improvement of Power Transformer Faults Diagnostic Using KNN Classifier With Decision Tree Principle // IEEE Access. - 2021. Vol. 9. - P. 81693-81701. - DOI: https://doi.org/10.1109/ACCESS.2021.3086135

24.Demirci, M., Gozde, H., Taplamacioglu, M. C. Comparative Dissolved Gas Analysis with Machine Learning and Traditional Methods // 2021 3rd International Congress on Human-Computer Interaction, Optimization and Robotic Applications (HORA). $\quad$ - 2021. - P. 1-6. - DOI: https://doi.org/10.1109/HORA52670.2021.9461371

25.Алексеев, Б. А. Контроль состояния крупных силовых трансформаторов. - Москва: НЦ ЭНАС, 2002. $-216 \mathrm{c}$.

26.Shutenko, O., Kulyk, O. Analysis of Gas Content in Oil-Filled Equipment with Low Energy Density Discharges // International Journal on Electrical Engineering and Informatics. - 2020. - Vol. 12, No. 2. - P. 258277. - DOI: https://doi.org/10.15676/ijeei.2020.12.2.6

27.Shutenko, O., Kulyk, O. Recognition of Overheating with Temperatures of $150-300^{\circ} \mathrm{C}$ by Analysis of Dissolved Gases in Oil // 2020 IEEE 4th International Conference on Intelligent Energy and Power Systems (IEPS). - IEEE, 2020. - P. 71-76. - DOI: https://doi.org/10.1109/IEPS51250.2020.9263145

28.Shutenko, O., Kulyk, O. Combined Defects Recognition in the Low and Medium Temperature Range by Results of Dissolved Gas Analysis // 2020 IEEE KhPI Week on Advanced Technology (KhPIWeek). - IEEE, 2020. - P. 65-70.

29.Шутенко, О. В. Анализ графических образцов построенных по результатам хроматографического анализа растворенных в масле газов для высоковольтных силовых трансформаторов с различными типами дефектов // Вісник Нац. техн. ун-ту «ХПІ» : зб. наук. пр. Сер. : Енергетика: надійність та енергоефективність. - Харків : НТУ "ХПІ", 2017. - № 31 (1253). - С. 97-121

30.Shutenko, O., Kulyk, O. Analysis of gas content in oil-filled equipment with defects for which ethane is the key gas // Lighting Engineering \& Power Engineering. - 2020. - Vol. 2, No. 58. - P. 78-87. DOI: https://doi.org/10.33042/2079-424X-2020-2-58-33-42

31.Ghoneim, S., Merabtine, N. Early stage transformer fault detection based on expertise method // International Journal of Electrical Electronics and Telecommunication Engineering. - 2013. - Vol. 44. - No. 2. - P. 1289-1294.

32.Шутенко, О. В. Анализ содержания газов в маслонаполненном оборудовании с дефектами электрического типа // Problemele Energeticii Regionale - Кишинев. - 2018 - №3 (38). - C 1-16. DOI: https://doi.org/10.5281/zenodo.2222331

33.Shutenko, O., Yakovenko, I. Analysis of Gas Content in High Voltage Equipment With Partial Discharges // 2018 IEEE 3rd International Conference on Intelligent Energy and Power Systems (IEPS). Kharkiv. 2018. - P. 347-352. DOI: https://doi.org/10.1109/IEPS.2018.8559534

34. Shutenko, O. Analysis of gas composition in oil-filled faulty equipment with acetylene as the key gas // Energetika. - 2019. - Vol 65, No 1. - P. 21-38. DOI: https://doi.org/10.6001/energetika.v65i1.3973.

35.Гмурман, В. Е. Теория вероятностей и математическая статистика. Учеб. пособие для вузов. Москва: Высш. шк., 1977. - 479 с.

36.Шутенко, О.В. Особенности динамики изменения критериев используемых для интерпретации результатов ХАРГ в силовых трансформаторах с разными типами дефектов // Новое в Российской электроэнергетике. - 2017. - № 9. - С. 30-49.

37.Shah, S. Online monitoring of transformer health using fuzzy logic approach // Proceedings of SARCIRAJ International Conference. - 2013 - P. 16-20. 
38.Wagh Nandkumar, Deshpande D.M. Fuzzy Decision on Transformer Fault Diagnosis using Dissolved Gas Analysis and IEC Ratio Codes // International Journal of Scientific \& Engineering Research. - 2013 - Vol. 4, Iss. 9. - P. 2503-2509.

\section{References:}

1.Kulyk O. Analysis of the diagnostic criteria used to defect type recognition based on the results of analysis of gases dissolved in oil. Bulletin of the National Technical University "KhPI". Series: Energy: Reliability and Energy Efficiency. 2020. № 1. P. 15-25. DOI: https://doi.org/10.20998/2224-0349.2020.01

2.Mineral oil-filled electrical equipment in service - Guidance on the interpretation of dissolved and free gases analysis: IEC 60599:2015. Geneva, Switzerland: International Electrotechnical Commission, 2015. 78 p.

3.IEEE Guide for the Interpretation of Gases Generated in Mineral Oil-Immersed Transformers: IEEE Std C57.104-2019. Piscataway, NJ, USA: Institute of Electrical and Electronics Engineers, 2019. 98 p. DOI: https://doi.org/10.1109/IEEESTD.2019.8890040

4.Diahnostyka maslonapovnenoho transformatornoho obladnannia za rezultatamy khromatohrafichnoho analizu vilnykh haziv, vidibranykh iz hazovoho rele, i haziv, rozchynenykh u izoliatsiinomu masli. Metodychni vkazivky [Diagnosis of oil-filled transformer equipment by chromatographic analysis of free gases sampled from the gas relay and gases dissolved in the insulating oil. Methodological guidelines]: SOU-N EE 46.501:2006. Kyiv, Ministry of Fuel and Energy of Ukraine, 2007. 91 p.

5.Metodicheskie ukazaniia po diagnostike razvivaiushchikhsia defektov transformatornogo oborudovaniia po rezultatam khromatograficheskogo analiza gazov, rastvorennykh v masle [Procedural guidelines for diagnostics of defects developing in transformer equipment using the results of chromatographic analysis of gases dissolved in the oil]: RD 153-34.0-46.302-00. Moscow, NTs ENAS Publ., 2001, 41 p.

6.Metodicheskie ukazaniia po tekhnicheskomu diagnostirovaniiu razvivaiushchikhsia defektov maslonapolnennogo vysokovoltnogo elektrooborudovaniia po rezultatam analiza gazov, rastvorennykh $\mathrm{v}$ mineralnom transformatornom masle [Methodological guidelines for the technical diagnosis of developing defects in oil-filled high-voltage electrical equipment based on the results of dissolved gas analysis]: STO 34.01-23-0032019. PJSC «Rosseti», 2019. 63 p.

7.Dornenburg E., Strittmater W. Monitoring Oil-Cooled Transformers by Gas Analysis. Brown Boveri Review. 1974. Vol. 61. P. 238-274.

8.Rogers R. IEEE and IEC Codes to Interpret Incipient faults in Transformers, Using Gas in Oil Analysis. IEEE Trans. on Electrical Insulation. 1978. Vol. 5, No. 38. P. 349-354. DOI: https://doi.org/10.1109/TEI.1978.298141

9.Müller R., Schliesing H., Soldner K. Die Beurteilung des Betriebszustandes von Transformatoren durch Gasanalyse. Elektrizitätswirtschaft. 1977. No. 76. P. 345-349.

10.Guideline for the refurbishment of electric power transformers. Electric Technology Research Association. 2009. Vol. 65. No. 1 (in Japanese).

11.Duval M. The Duval Triangle for load tap changers non-mineral oils and low temperature faults in transformers. IEEE Electrical Insulation Magazine. 2008. Vol. 24, No. 6. P. 22-29. DOI: https://doi.org/10.1109/MEI.2008.4665347

12.Bräsel E. Universal Fault Gas Triangle for Transformer Diagnostics. GATRON GmbH. P. 1-6.

13.Kawamura T., Kawada H., Ando K., Yamaoka M., Maeda T., Takatsu T. Analyzing gases dissolved in oil and its application to maintenance of transformers. Paris, SIGRE Session Report 12-05, 1986. 5 p.

14. Naganathan G. et al. Internal fault diagnosis of power transformer using artificial neural network. Materials Today: Proceedings. 2021. Vol. 2021. DOI: https://doi.org/10.1016/j.matpr.2021.02.206

15.Ahmadi S.-A., Sanaye-Pasand M. A Robust Multi-Layer Framework for Online Condition Assessment of Power Transformers. IEEE Transactions on Power Delivery. 2021. DOI: https://doi.org/10.1109/TPWRD.2021.3074545.

16.Genc S., Karagol S. Fuzzy Logic Application in DGA Methods to Classify Fault Type in Power Transformer. 2020 International Congress on Human-Computer Interaction, Optimization and Robotic Applications (HORA). 2020. P. 1-4. DOI: https://doi.org/10.1109/HORA49412.2020.9152896

17.Apte R., Wajirabadkar A. Incipient Fault Diagnosis of Transformer by DGA Using Fuzzy Logic. 2018 IEEE International Conference on Power Electronics, Drives and Energy Systems (PEDES). 2018. P. 1-5. DOI: https://doi.org/10.1109/PEDES.2018.8707928

18.Kari T. et al An integrated method of ANFIS and Dempster-Shafer theory for fault diagnosis of power transformer. IEEE Transactions on Dielectrics and Electrical Insulation. 2018. Vol. 25, No. 1. P. 360-371. DOI: https://doi.org/10.1109/TDEI.2018.006746

19.Tightiz L. et al. An intelligent system based on optimized ANFIS and association rules for power transformer fault diagnosis. ISA Transactions. 2020. Vol. 103. P. 63-74. DOI: https://doi.org/https://doi.org/10.1016/j.isatra.2020.03.022 
20.Dias L. et al. An unsupervised approach for fault diagnosis of power transformers. Quality and Reliability Engineering International. 2021. DOI: https://doi.org/10.1002/qre.2892

21.Ghoneim S. S. M., Farrag T. A., Rashed A. A., El-Kenawy E.-S. M., Ibrahim A., Adaptive Dynamic Meta-Heuristics for Feature Selection and Classification in Diagnostic Accuracy of Transformer Faults. IEEE Access. 2021. Vol. 9. P. 78324-78340. DOI: https://doi.org/10.1109/ACCESS.2021.3083593

22.Odongo G., Musabe R., Hanyurwimfura D. A Multinomial DGA Classifier for Incipient Fault Detection in Oil-Impregnated Power Transformers. Algorithms. 2021. Vol. 14, No. 4. P. $128 . \quad$ DOI: http://dx.doi.org/10.3390/a14040128

23.Kherif O., Benmahamed Y., Teguar M., Boubakeur A., Ghoneim S. S. M. Accuracy Improvement of Power Transformer Faults Diagnostic Using KNN Classifier With Decision Tree Principle. IEEE Access. 2021. Vol. 9. P. 81693-81701. DOI: https://doi.org/10.1109/ACCESS.2021.3086135

24.Demirci M., Gozde H., Taplamacioglu M. C. Comparative Dissolved Gas Analysis with Machine Learning and Traditional Methods. 2021 3rd International Congress on Human-Computer Interaction, Optimization and Robotic Applications (HORA). 2021. P. 1-6. DOI: https://doi.org/10.1109/HORA52670.2021.9461371

25.Alekseev B. A. Kontrol sostoianiia (diagnostika) krupnykh silovykh transformatorov [Condition monitoring (diagnostics) of large power transformers]. Moscow, NTs ENAS Publ., 2002. 216 p.

26.Shutenko O., Kulyk O. Analysis of Gas Content in Oil-Filled Equipment with Low Energy Density Discharges. International Journal on Electrical Engineering and Informatics. 2020. Vol. 12, No. 2. P. 258-277. DOI: https://doi.org/10.15676/ijeei.2020.12.2.6

27. Shutenko O., Kulyk O. Recognition of Overheating with Temperatures of $150-300^{\circ} \mathrm{C}$ by Analysis of Dissolved Gases in Oil. 2020 IEEE 4th International Conference on Intelligent Energy and Power Systems (IEPS). IEEE, 2020. P. 71-76. DOI: https://doi.org/10.1109/IEPS51250.2020.9263145

28.Shutenko O., Kulyk O. Combined Defects Recognition in the Low and Medium Temperature Range by Results of Dissolved Gas Analysis. 2020 IEEE KhPI Week on Advanced Technology (KhPIWeek). IEEE, 2020. P. 65-70. DOI: https://doi.org/10.1109/KhPIWeek51551.2020.9250131

29.Shutenko O. V. Analiz graficheskikh obraztsov postroennykh po rezultatam khromatograficheskogo analiza rastvorennykh $\mathrm{v}$ masle gazov dlia vysokovoltnykh silovykh transformatorov s razlichnymi tipami defektov [Analysis of graphical samples of gases constructed for chromatographic analysis of gases dissolved in oil for highvoltage power transformers with various types of defects]. Bulletin of the National Technical University "KhPI": a collection of scientific papers. Thematic issue: Energetics: reliability and energy efficiency. 2017. No. 31 (1253). P. 97-121.

30.Shutenko O., Kulyk O. Analysis of gas content in oil-filled equipment with defects for which ethane is the key gas. Lighting Engineering \& Power Engineering. 2020. Vol. 2, No. 58. P. 78-87.

31.Ghoneim S., Merabtine N. Early stage transformer fault detection based on expertise method. International Journal of Electrical Electronics and Telecommunication Engineering. 2013. Vol. 44. No. 2. P. 12891294.

32. Shutenko O. V. Analiz soderzhaniia gazov v maslonapolnennom oborudovanii s defektami elektricheskogo tipa [Analysis of the content of gases in oil-filled equipment with electrical defects]. PROBLEMELE ENERGETICII REGIONALE. 2018 No. $3 \quad$ (38). P. $\quad$ 1-16. DOI: https://doi.org/10.5281/zenodo.2222331

33.Shutenko O., Yakovenko I. Analysis of Gas Content in High Voltage Equipment With Partial Discharges. 2018 IEEE 3rd International Conference on Intelligent Energy and Power Systems (IEPS). Kharkiv. 2018. P. 347-352.

34. Shutenko O. Analysis of gas composition in oil-filled faulty equipment with acetylene as the key gas. Energetika. 2019. Vol 65, No 1. P. 21-38. DOI: https://doi.org/10.6001/energetika.v65i1.3973

35.Gmurman V. E. Teoriia veroiatnostei i matematicheskaia statistika. Ucheb. posobie dlia vuzov [Probability Theory and Mathematical Statistics. Textbook for Universities.]. Moscow, High school Publ., 1977. 479 p.

36. Shutenko O. V. Osobennosti dinamiki izmeneniia kriteriev ispolzuemykh dlia interpretatsii rezultatov KhARG v silovykh transformatorakh s raznymi tipami defektov [Peculiarities of the dynamics of the criteria used for the interpretation of DGA results in power transformers with different types of defects]. New in the Russian electricity sector. 2017. No. 9. P. 30-49.

37.Shah S. Online monitoring of transformer health using fuzzy logic approach. Proceedings of SARCIRAJ International Conference. 2013 P. 16-20.

38.Wagh Nandkumar, Deshpande D.M. Fuzzy Decision on Transformer Fault Diagnosis using Dissolved Gas Analysis and IEC Ratio Codes. International Journal of Scientific \& Engineering Research. 2013. Vol. 4. Iss. 9. P. 2503-2509. 